\title{
頸椎疾患に対するMRIの診断的価值
}

\author{
南風病院
}

$\begin{array}{cllll}\text { 脇 丸 } & \text { 孝・米 } & \text { 和 徳 } \\ \text { 鮫 島 浩 } & \text { 司 } & & \\ \text { 鹿児島大学整形外科 } & & & \\ \text { 酒 匂 } & \text { 崇・寺 } & & \\ \text { 下 野 哲 朗 } & & & \text { 歩 }\end{array}$

\section{Diagnostic Value of MRI of Cervical Spine}

by

\section{Kazutaka Wakimaru, Kazunori Yone and Koji Sameshima \\ Department of Orthopaedic Surgery, \\ Nanpuh Hospital, Kagoshima}

\section{Takashi Sakou, Ayumu Terada and Tetsuro Shimono}

Department of Orthopaedic Surgery, Faculty of Medicine, Kagoshima University, Kagoshima

In order to evaluate diagnostic value of MRI of cervical spine, 439 patients who were examined by MRI were reviewed.

In cases such as disease of the craniocervical junction, intraspinal neoplasm, tumor of the spine, syringomyelia, herniation of cervical disk, and spinal sepsis, MRI was superior or equal to other imaging methods such as plane $\mathrm{X}-\mathrm{P}$, tomography, myelography and CT scan.

On the other hand, MRI was inferior to other imaging methods in case of cervical spondylosis and O. P. L. L.

\section{はじめに}

磁気共鳴映像 (以下 MRI と略) は，軟部組織の描出 能に優れ，また任意の断面が得られ，しかも放射線被 爆がないことから, 臨床導入以来脊椎, 脊髄疾患の診 断に広く用いられ，その有用性は確立されつつある。 われわれは, 頸椎疾患に対する MRI の診断学的有用性 と問題点について検討を加えたので報告する。

\section{対象および方法}

1986 年 8 月以降頸椎 MRI を施行した 439 例を対象 とした。

使用装置は東芝社製 MRT 22A（静磁場強度 0.22 Tesla)である.パルス系列は主に short SE 法(TR 500/ TE $30 \mathrm{msec}$ ) と long SE 法 (TR 2000/TE $60 \mathrm{msec}$.)
を用いた. スライス厚 $10 \mathrm{~mm} に て$ 矢状断面像を，また $5 \mathrm{~mm}$ にて横断面像を得た. MR 信号受信用には直径 20 $\mathrm{cm}$ の表面コイルと直径 $25 \mathrm{~cm}$ の頭頸部用コイルを使用 した.

\section{結果}

\section{1. 頭蓋頸椎移行部の病変}

頭蓋底陥入症, 環軸椎亜脱臼などの診断は, MRI で は, 造影剂を用いず一回の検查にて骨および中枢神経 系の解剖学的異常を明瞭に描出することが可能であっ た.

\section{2. 椎間板ヘルニア}

椎間板に存在する椎間板物質と同じ信号強度の突出 物が椎体後縁より後方へ突出していることより確認で きた. またへルニアの局在性については椎間にそって 
横断面像を撮像することによって判定可能であった(図 1).

\section{3. 春髄腫湯}

ほとんどの腫瘍の範囲が正確に同定でき, 手術術式 を決定するうえできわめて参考になった。しかしなが ら現状では，特殊な例を除き腫瘍の組織診断を信号強 度，T1, T2 值から得ることは困難であった。

4. 脊髄空洞症

$\mathrm{T} 1$ 強調像にて syrinx は脊䯣内低信号領域として描 出された。

\section{5. 蓨椎腫瘍}

病巣の広がりが明瞭に描出され，骨シンチグラムそ

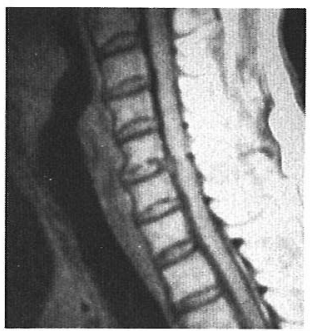

a

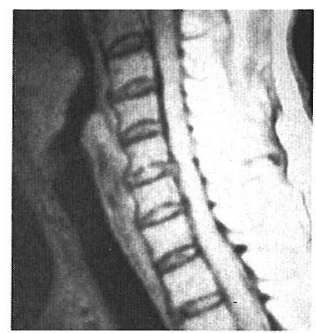

b
図 163 才, 男性, 頸椎椎間板へルニア.

a. MRI short SE 矢状断面像 b. MRI long SE 矢状断面像 矢状断面像にて $C 5 / 6$ 椎間板の後方への突出と 脊髄への圧迫を認める。脊髄造影でも同部位に てミエロ柱の完全停止像を認めた。

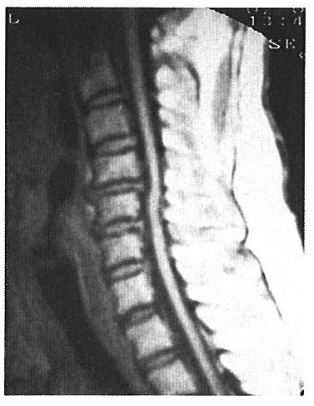

a

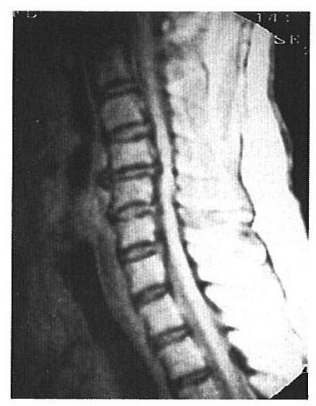

b
図 267 才, 男性, 頸椎症性脊㵦症。

a. MRI short SE 矢状断面像

b. MRI long SE 矢状断面像

short SE 像では, C3/4, 4/5, 5/6 椎間板の後方 への突出と脊䯣前後径の狭小化を認める. long $\mathrm{SE}$ 像では, C3〜 6の脊髄内高信号領域を認める. 春髄造影では, C3〜 6 のミエロ柱の狭小化と菲薄 化を認めた。
の他で転移と診断された部位とよく一致した。

6. 化膿性脊椎炎

単純レントゲン写真に比べ，より早期から椎体，椎 間板への病巣の広がりが観察された。

7. 変形性頸椎症扝よび鞄帯骨化症

骨棘扔よび鞄帯骨化部は無信号領域となるため，骨 䊂, 靱帯骨化部の大きさおよび形態の観察は不可能で あった（図 2 )。

今回，われわれは脊髄前後径を計測することにより 脊髄圧迫の程度を知ることが可能ではないかと考え, short SE 矢状断面像から脊髄前後径の計測を行った。 その結果, 脊髄症状群の最狭部脊髄前後径は, 無症状 群にくらべ有意に小さな值を取った。しかしながら最 狭部脊髄前後径と日整会脊髄症判定基準の間に相関関 係は認められなかった。さらに，long SE 像を用いて 脊髄内高信号領域の観察を行ったが，高信号領域の有 無によって，日整会脊髅症判定基準に有意の差を認め なかった。

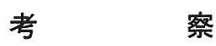

MRI は頸椎疾患の診断に際しては, 脊䯣空洞症, 䯣 内腫瘍などの春骵内病変に対してもっとも有力であり， その診断精度の高さのみならず，一回の検査で無侵襲 に広範な病変を描出できる点で第一選択とすべき画像 診断法である ${ }^{3)}$.

髄外腫瘍，椎間板ヘルニア，頭蓋頸椎移行部の病変 などでも MRI は造影剤なしで診断でき,ことに従来の 検査で有用な所見を得にくい頭蓋頸椎移行部病変では, 同部を形態的, 立体的に把握するうえで有効である ${ }^{122)}$.

それに反して，変形性脊椎症や靶帯骨化症では，骨 棘や靱帯骨化部は無信号領域となるために直接描出さ れず，MRI はその観察に適さない。また, short SE 像 で得られる脊髄前後径は脊髄圧迫の程度の目安となる が，臨床症状と必ずしも一致せず，責任病巣の決定に 際しては，より瀻細な描出力を有する Myelography CTM を必要とする。しかしながら，これらの疾患にお いても従来の画像診断法では得られなかった脊髄内高 信号領域などの脊䯣血流あるいは代謝の変化を示唆す る情報が得られ ${ }^{4}$ ，今後，空間分解能の向上とともに， その診断学的有用性も増すものと思われる。

\section{ま と め}

1. MRI がもつとも有用な情報を提供した疾患とし 
ては, 頭蓋頸椎移行部病変, 脊髄腫瘍, 脊䯣空洞症, 椎間板ヘルニア, 化膿性脊椎炎などがあった。

2. 変形性頸椎症, 靱帯骨化症でも有用な情報は得 られたが, いくつかの問題点も見受けられた.

\section{参 考 文 献}

1) J.W. Berkelbach et al.: MRI in neurosurgical diagnosis and management of cran iocervical junotion and cervical spine pathology. Clin. Neurol. Neurosurg. 88-4 : 245-251, 1986.

2) F. C. Breedveld. et al. : Magnetic resonance imaging in the evaluation of the rheumatoiod arthritis and subluxations of the cervical spine. Arthritis and Rheumatism. 30-6 : 624-629, 1987.

3) M. T. Modic et al. : Magnetic resonance imaging of the cervical spine. A. J. R. 141 : 1129-1136, 1983.

4）高橋睦正・他：頸部脊髄髄外病変の MRI. 臨放, 32 : 671-679, 1987.

\section{質 問 \\ 九州大学 柴田堅一郎}

OPLL などの MRI は骨化そのものは低信号ですが,
逆に脊髄に対する情報はそれなりにあると思いますが。

$$
\text { 解 答南風病院 脇丸一孝 }
$$

MRI では骨棘や靯帯骨化部を直接所見としてとらえ ることができない点で, 有用と考えにくい. 春髄圧迫 などの間接所見をとらえる点では, 有用と考えられる.

\section{解 答南風病院 脇丸 一孝}

MRI による脊髄前後径の計測值は

$$
\begin{array}{rrr}
\text { 無症状群 } & \text { 男性 } & 6.9 \pm 0.37 \mathrm{~mm} \\
& \text { 女性 } & 7.1 \pm 0.54 \mathrm{~mm} \\
\text { 脊䯣症状群 } & \text { 男性 } & 4.6 \pm 0.93 \mathrm{~mm} \\
\text { 女性 } & 4.5 \pm 0.83 \mathrm{~mm} \\
\text { (画像内スケールにて換算済) }
\end{array}
$$

脊髄症状群で有意に小さかった。（ $\mathrm{P}<0.05 ）$ 